特 集

\title{
骨伝導スピーカの技術と特性解析
}

\section{Technology for Bone Conduction Speaker and its Characteristics Analysis}

\author{
北川 亘 ${ }^{* 1}$ (正員)，竹下 隆晴*1
}

\author{
Wataru KITAGAWA (Mem.) and Takaharu TAKESHITA
}

\begin{abstract}
This paper presents the principle, characteristics and its analysis for bone conduction speaker. Bone conduction speaker has used under the sound noise, openable ear environment or by impaired hearing people because it is able to send the sound vibration directly to ear through the bone. In this article, introduce the 2 type of bone conduction speaker, then it is mentioned its analysis and results.

Keywords: bone conduction speaker, electromagnetic analysis, voice coil
\end{abstract}

\section{1 緒言}

音を聞くという動作は，健常者であれば日ごろ意識 せず行われているものである。言うまでもないことで はあるが，音は振動であり，その波の振幅が音の大き さ, 周波数が高低である。この波は, Fig.1 に示される, 耳介によって集められ，外耳道が中耳に波を伝える。 さらにこの波は外耳と中耳の境目に備わる鼓膜に伝わ り，鼓膜が振動する。この振動が中耳に伝わる。中耳 には，3つの耳小骨と呼ばれる骨があり，この耳小骨 を経由して内耳に伝わっていく。内耳には蝸牛と呼ば れるリンパ液が入っている器官であり, 振動によって このリンパ液が振れ感覚神経によってその振れが電気 信号に変えられ脳に伝わるという仕組みである。この 複雑な仕組みによって伝わる音を気導音と呼ぶ。一方, 骨伝導はその名の通り, 骨を仲介して音を伝える仕組 みである。骨導音も実は我々が意識せずとも聞いてい る音である。自分の声にマイクを通し話寸声，もしく は留守番電話等に録音した自分の声を客観的に聞いて みると, いつも自分が話している声とは違うように聞 こえる。これは骨導音の影響である。骨導音をよく感 じるには，耳を塞いだ状態で話してみるとよい。その とき自分の声は，空気を伝わらず，頭部や顔面におけ る頭蓋骨を経由し，直接内耳に伝わる音である。

連絡先： 北川 亘, $\overline{\mathrm{T}} 466-8555$ 名古屋市昭和区御器所町, 名古屋工業大学大学院 工学研究科 電気・機械工学専攻, e-mail: kitagawa.wataru@nitech.ac.jp

*1 名古屋工業大学

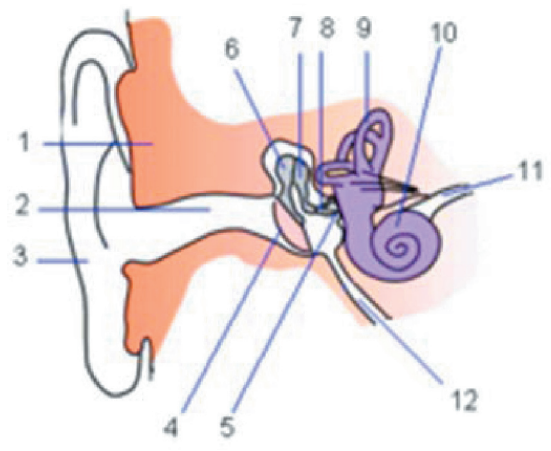
1 , 筋肉
2, 外耳道
3, 耳介
4 , 鼓膜
5 , 鼓室
6, ッチ骨
7, キヌタ骨
8, アブミ骨
9, 半規管
10 , 螖牛
11, 内耳神経
12, 耳管

Fig.1 Structure of ear.

有名なのは, 作曲家ベートーベンに関する逸話である。 ベートーベンが難聴となったとき, 彼は自分の歯にタ クトを咥えその先端をピアノにくっつけ, 音の振動を 直接聞いていたといわれている。これが本当であるな らば，まぎれもなく骨導音を利用していたと考えられ る。本稿では, この骨導音を利用した，骨伝導スピー カの原理，技術，その特性等について述べる。

\section{2 骨伝導スピーカの製品}

骨伝導スピーカは日本国内において，2000 年を過 ぎたあたりから，その技術が注目されはじめ, 数年 後, 骨伝導スピーカを利用した電話機が登場してい る。その後, 携帯電話でも骨伝導スピーカを搭載した ものが出始め, その技術は加速した。しかし, 一般消 費者の関心はその当時は非常に低く, それら製品は時 代とともに少なくなっていく。そんな中，一般消費者 
にはほとんど受け入れられなかったが，医療・看護系 では注目されつつあった。難聴の障害を持つ患者や, 音が聞こえにくくなった年配の方々を対象とした製品 群である。医療・介護機器メーカでは, 骨伝導補聴器 や骨伝導増幅器として継続して開発を続け, その技術 を高めてきた。この間, いくつかの製品タイプが登場 している。

・ 耳の中に入れるイヤホンタイプ

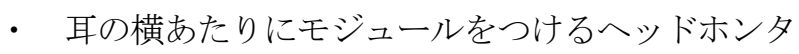
イプ

・ 眼鏡のツル部分にモジュールを装着するタイプ

・歯にモジュールを装着するタイプ

・耳にモジュールを挟むクリップタイプ

どのタイプも, 骨を媒介して直接振動を伝えるため, その原理は変わらない。骨導音の特徵として，一般 的に $30 \mathrm{kHz}$ 程度以上が不明瞭であるといわれていた が，近年では，その特性を大幅に改善したハイレゾリ ューションモジュールも市販されつつある。

\section{3 骨伝導スピーカ基本構造と原理}

\section{1 一般構造}

本章では, ヘッドホンタイプの骨伝導スピーカの構 造について述べる。骨伝導スピーカの一般的な構造は ダイナミクスピーカ方式を利用している[1]。Fig.2にダ イナミクススピーカの構造例を示す。この構造例では 可動コイル，振動板及びリング状磁石で構成されてい る。可動コイルは電流が流れることによって上下に振 動しそれに伴い振動板が振動し, その振動が頭蓋骨な どの骨を通じて聴覚神経に伝わることで音が聞こえる 仕組みとなっている。

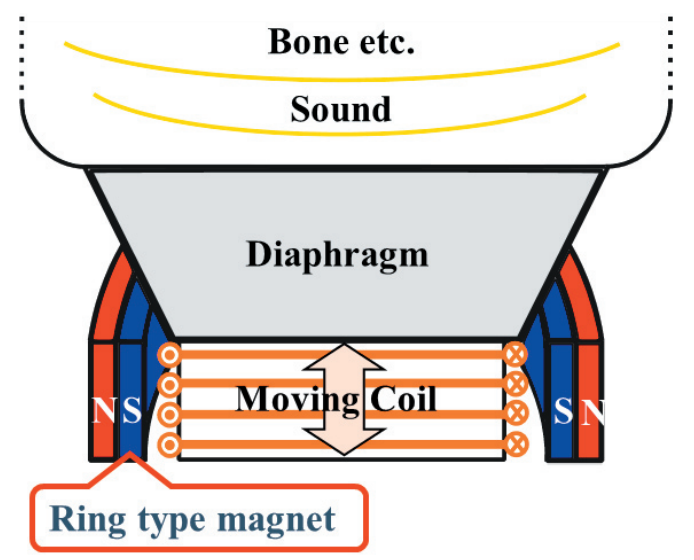

Fig.2 Type of moving coil loudspeaker.

\section{2 基本ボイスコイルモデル}

本節では, ダイナミクススピーカ方式の中で, 最も 基本的な構造である基本ボイスコイルモデル[2,3]を紹 介寸る。Fig.3がヘッドホンタイプの外観図である。サ ンプルであるので，モジュールは先端の透明な樹脂の 中に入っていることが分かる。Fig.4にそのモジュール 本体である基本ボイスコイルモデルの全体構造を示す。 この構造はマグネット，ヨーク，コイル，コイルケー ス, 樹脂ケース, 樹脂力バー及び振動板で構成されて いる。また, マグネットの剥離を防止するために, 樹

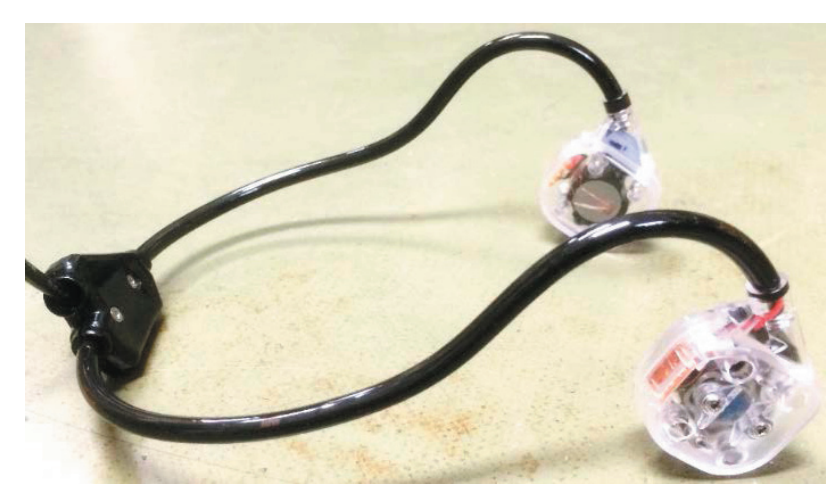

Fig.3 Sample of Headphone type.

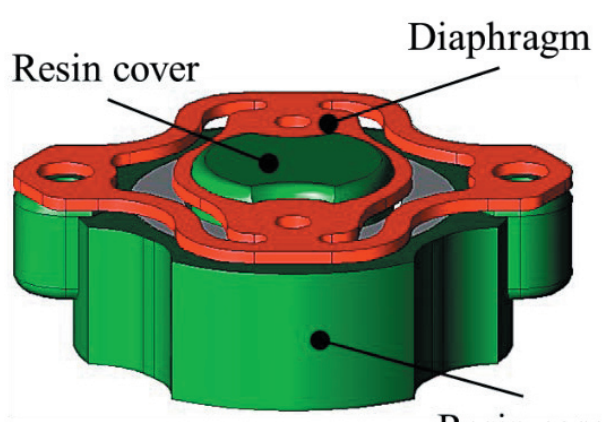

(a) Outside structure.

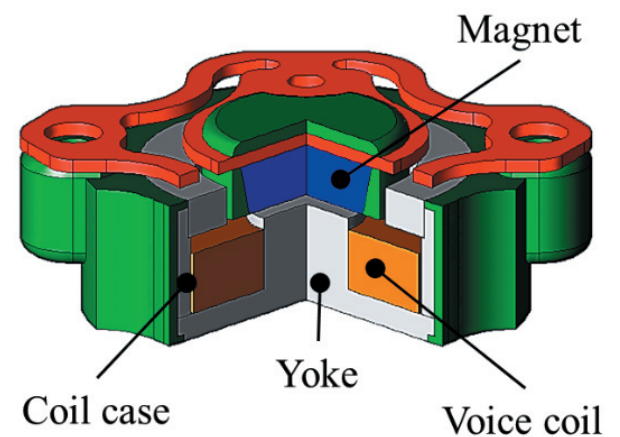

(b) Inside structure.

Fig.4 Whole structure of basic voice coil model. 


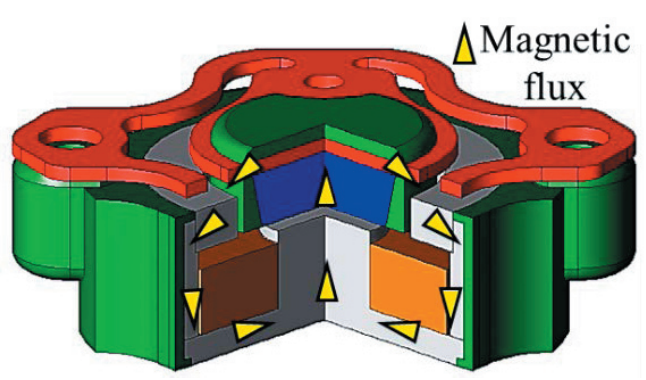

Fig.5 Magnetic flux flow.

脂カバーを用いてマグネットを支持している。この構 造はコイルケースに磁性体の近接部を設けているため, マグネットから出た磁束の多くが振動板上部の空気で はなく近接部に流れるような構造となっている。さら に, マグネットから出た磁束が直接マグネットへ戻り 難く寸るためにマグネットの形状は円錐台を採用して いる。したがってこの構造の振動板上面の漏孔磁束は 少なくなり，磁路の無駄がほとんどない構造である。

Fig.5 にリングマグネットモデルの磁束の流れを示す。 これらの構造の駆動部はヨークとボイスコイルによっ て構成され，ヨークの磁極部はボイスコイルの中央か ら円柱状に突き出ていおり, ボイスコイルはヨークの 磁極部の周囲に巻かれている。振動部はマグネットと 振動板によって構成され，マグネットは振動板の下部 に接着されており, ヨークの磁極部と向かい合ってい る。また，ヨークとマグネットの間にはギャップが設 けられている。これらの構造はボイスコイルに音声信 号による電流が流れることによって，ヨークとマグネ ットの間の吸引力が変化し，それに伴いマグネットと 振動板が振動し，それを頭蓋骨などの骨に当てること によって音が聞こえる仕組みとなっている。駆動原理 としては，マグネットは軸方向上向きに着磁されてお り, ボイスコイルに反時計回りの電流が流れる場合, ヨークを通るマグネットによる磁束とボイスコイルに 流れる電流による磁束が同方向に流れる。つまり，ヨ ークを通る磁束が強め界磁となり, マグネットとヨー クの間の磁気吸引力が強められる。ボイスコイルに時 計回りの電流が流れる場合, ヨークを通るマグットに よる磁束とボイスコイルに流れる電流による磁束が逆 方向に流れる。つまり，ヨークを通る磁束が弱め界磁 となり, マグネットとヨークの間の磁気吸引力が弱め られる。以上のように, ボイスコイルに流れる電流の 向きが時刻と共に変化することによって, マグネット とヨークの間には一定のバイアスが掛かりながら磁気
吸引力は変化し，振動板が振動する。

\section{3 高低音出力型 2 way モデル}

前節では, 基本ボイスコイルモデルの構造を示した が，このモデルでは，可聴音域における全周波数をカ バーできないため，振動板を上部と下部に高音域用振 動板, 低音域用振動板として設置した 2 way モデルも 提案されている[4]。本節ではその構造を紹介寸る。

Fig.6 に 2 way モデルの全体構造を示す。この構造は振 動板, 樹脂カバー, マグネット, ボイスコイル, 非磁 性体板，ヨーク，コイルケース，樹脂ケースで構成さ れている。基本ボイスコイルモデルと同様にマグネッ トの剥離を防止するために樹脂力バーを設置しており， ヨークを支持するためにステンレス材の非磁性体板を 設置している。マグネットの体積は高出力を得るため にそれぞれ基本ボイスコイルモデルと同じ体積のもの を使用している。そのため使用しているマグネット量 はリングマグネットモデルの 2 倍となっている。マグ ネット量が倍増し，マグネットとヨークの磁気吸引力 が増加するため, 基本ボイスコイルモデルよりもギヤ ップを広げている。次に 2 way モデルの特徽を述べる。 この構造は上部に高周波域に適した基本ボイスコイル モデルと等しい形状の振動板を設置しており，下部に は振動板のアーム部分や天板部分の厚みを変更するこ とで低周波域に適した振動板を設置している。下部の 振動板の設計方法については後述する。マグネットは 共に上向きに着磁されており，上部マグネットから出

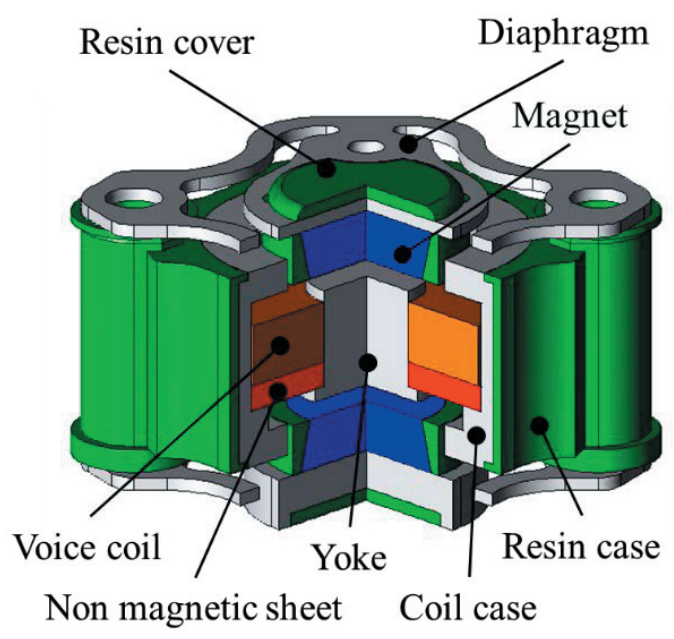

Fig.6 Whole structure of 2 way model. 
た磁束がコイルケース，下部マグネット及びヨークを 通ってループする。

\section{4 骨伝導スピーカの特性解析}

\section{1 電磁界解析諸元}

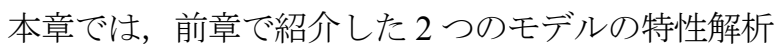
について述べる。両モデルのボイスコイルに流寸電流 は正弦波で, 反時計回りを正としている。電流の大き さは $14.76 \mathrm{~mA}$ とし, 実際の使用条件と合わせている。 また，周波数は $100-4000 \mathrm{~Hz}$ の範囲を用いており，100$1000 \mathrm{~Hz}$ は $100 \mathrm{~Hz}$ 刻みで 1000-4000 Hz $500 \mathrm{~Hz}$ 刻み で解析する。一般的に，人間の可聴域は $20 \mathrm{~Hz}-20 \mathrm{kHz}$ と言われているが，本解析でこの範囲の周波数を用い ているのは, $100 \mathrm{~Hz}$ 以下の低周波数の音, 及び $4000 \mathrm{~Hz}$ 以上の高周波数の音はその多くが骨に吸収されてしま い，聴覚神経まで届かないことが実験的に分かってい るためである。本解析では音声信号電流として正弦波 電流を使用して解析している。また, 積分路はヨーク とマグネットの中間部分にとっているため, ギャップ 部分は積分路付近となるため, 他の部品よりもメッシ ユを細かく分割している。

\section{2 音圧レベル}

音圧は大気圧に対する圧力の変化である。人が聞く ことが出来る最小の音圧は, $20 \mu \mathrm{Pa}$ である。もし周波 数が等しいならば, 高い音圧の音が大きな音である。 しかし，一般的には音を評価する時に音圧は使われず， 音圧レベル(SPL)が使用される[5]。音圧レベルは各節 点の音圧 $P$ と最小音圧 $P_{r e f}$ の割合の対数をとったもの であり, 可聴音圧レベルは, $0 \mathrm{~dB}$ から $140 \mathrm{~dB}$ である。 音圧レベルは次式で与えられる。

$$
S P L=20 \log _{10}\left(\frac{|P|}{\sqrt{2} P_{\text {ref }}}\right)
$$

本解析において, 各節点の音圧 $P$ は振幅值で, 最小音 圧 $P_{r e f}$ は $20 \mu \mathrm{Pa}$ で一定值である。各節点の音圧 $P$ は, 音圧条件に設定された面の変位速度や振動モード及び 測定地点によって一意に決まる。音圧条件とは, 本解 析で設定される条件の一つであり, 一般的に変位する 部分の表面を音圧条件に設定している。そのため, 本 解析では振動板とマグネットで構成される振動部の表 面を音圧条件に設定する。振動モードは固有モード解
析[6]の結果から得られ, 測定地点は評価面と呼ばれる 面で定義される。これらの条件から, 各節点の音圧 $P$ は, 評価面における波の重祆合わせの理によって計算 される。

\section{3 電磁界解析結果}

Fig.7 に基本ボイスコイルモデルの推力特性を示す。 ボイスコイルを流れる電流は大きさが $14.76 \mathrm{~mA}$ で, 周波数は $100-1000 \mathrm{~Hz}$ を $100 \mathrm{~Hz}$ 刻みとする。しかし解 析結果より, 周波数によって推力特性の peak-to-peak 值 及び平均值は変化しないことが確認されたため, 100 $\mathrm{Hz}$ 以外の周波数は省略寸る。またこの推力特性は, 電 磁界解析の結果から得られた磁束密度より, マクスウ エルの応力法[7]によって計算されている。積分路はヨ ークとマグネットの間にあるギャップの中間部分に取 っている。Fig.7より, 正弦波状の推力特性が得られて おり，正弦波電流に対応していることからこの構造は 原理通りに動作していることが確認できる。 peak-topeak 值は $0.038 \mathrm{~N}$, 平均值は-3.33 N である。Fig. 8 に 2 way モデルの推力特性を示す。 2 way モデルも同様に 周波数によらず，推力特性の peak-to-peak 值及び平均 值は等しいため, $100 \mathrm{~Hz}$ 以外の周波数の推力特性は省 略する。Fig.8 (a)より, 2 way モデルの上部のギャップ の推力特性の peak-to-peak 值は $0.01 \mathrm{~N}$ であり, 平均值 は-1.06 N である。また, Fig.8 (b)より，下部のギャッ プの推力特性の peak-to-peak 值は $0.01 \mathrm{~N}$ であり, 平均 值は- $1.10 \mathrm{~N}$ である。基本ボイスコイルモデルと比較し て, 上下ギャップ間の推力特性は peak-to-peak 值及び 平均值共に大きく低下しているのは 2 way モデルのマ グネットの体積が基本ボイスコイルモデルと比較して, 半分であることや, 磁路が長くなった上, 空気部分を 通る磁束が多くなったことが主な理由である。

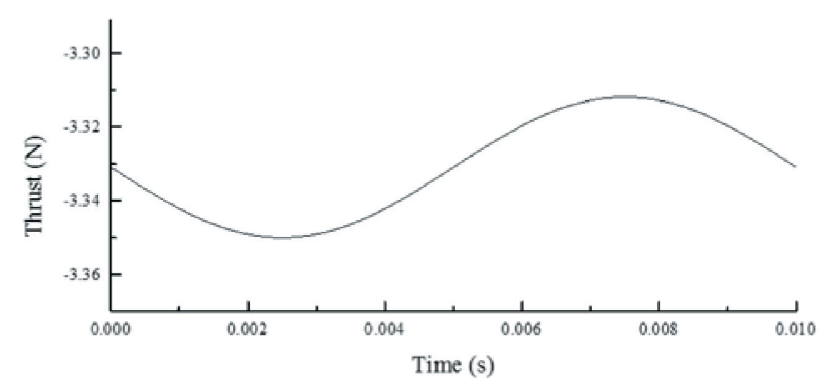

Fig.7 Thrust characteristic of basic voice coil model. 


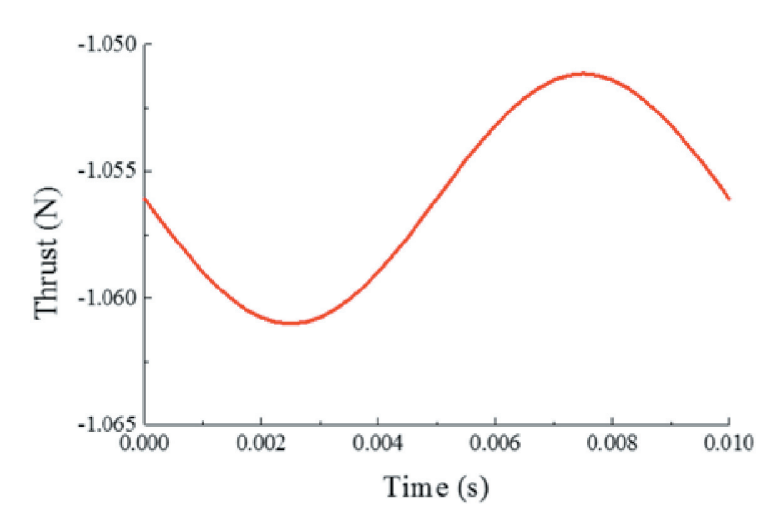

(a) Thrust characteristic of upper part.

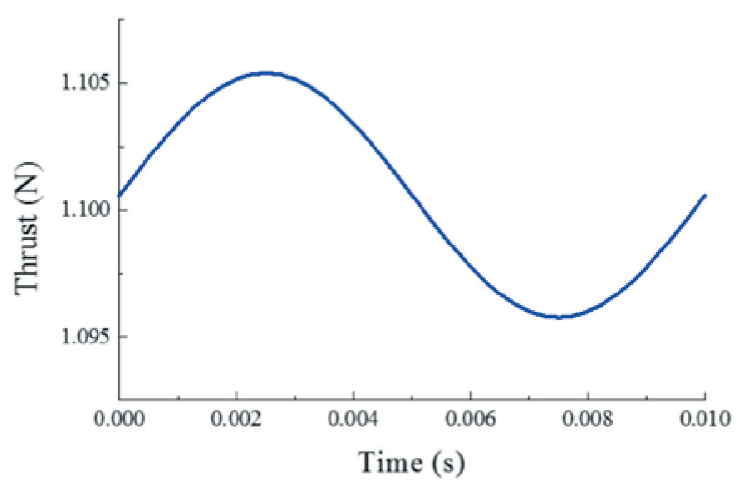

(b) Thrust characteristic of lower part.

Fig.8 Thrust characteristic of 2 way model.

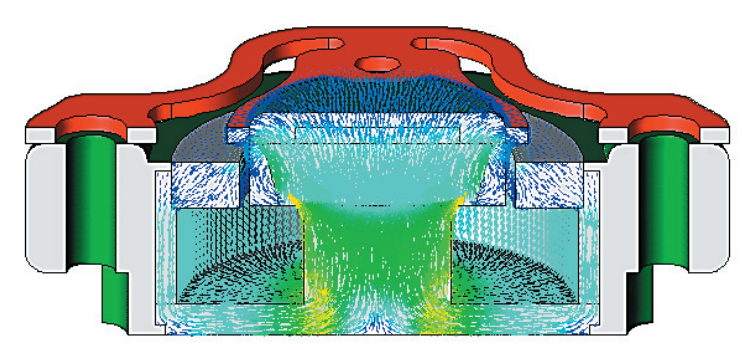

(a) Basic voice coil model.

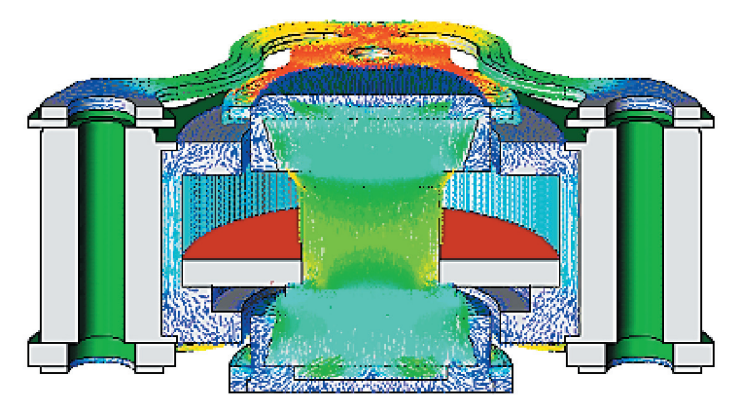

(b) 2 way model.

Fig.9 Distribution for magnetic flux density of each structure.
Fig.9 に基本ボイスコイルモデルと 2 way モデルの磁 束密度分布を示す。解析条件は前節と等しいため省略 する。磁束密度の範囲は 0-1.63 T としており, 2 way モ デルの振動板，ヨーク及びコイルケースの材料である ステンレス材の飽和磁束密度と合わせている。Fig.9 よ り，共にヨークは飽和していないことが確認できる。

\section{4 音圧レベル解析結果}

Fig.10に 基本ボイスコイルモデルと 2 way モデルの 音圧レベルのグラフを示す。これらは電磁界数值解析 の推力特性及び固有モード解析の結果を入力荷重とし た連成解析によって得られた結果である。音圧条件は 振動板とマグネットで構成される振動部の表面とし, 評価面はそれぞれ振動板に接する球面とする。Fig.10 より，基本ボイスコイルモデルと 2 way モデルは共に 可聴音を生じており, $100-1000 \mathrm{~Hz}$ の 2 way モデルの音 圧レベルは基本ボイスコイルモデルと比較すると $16.1 \%$ 高い。また 1000-4000 Hz における音圧レベルは 共に同等の值が得られた。

\section{5 測定結果}

1.63'本節では実機検証の際に用いた実験条件について 説明する。サンプルについては基本ボイスコイルモデ ルと 2 way モデルの測定を行った。実験方法として, はじめにファンクションジェネレータを用いてボイス コイルに 10-20 kHz の正弦波電流を印加寸る。その際 に発生する振動を人工マストイドで検出し, チャージ コンディションアンプを介してFFTアナライザで読み 取る。出力は, 1/3 オクターブ解析結果である。Fig.11Fig.12 に実験結果を示す。Fig.11 より, 基本ボイスコイ
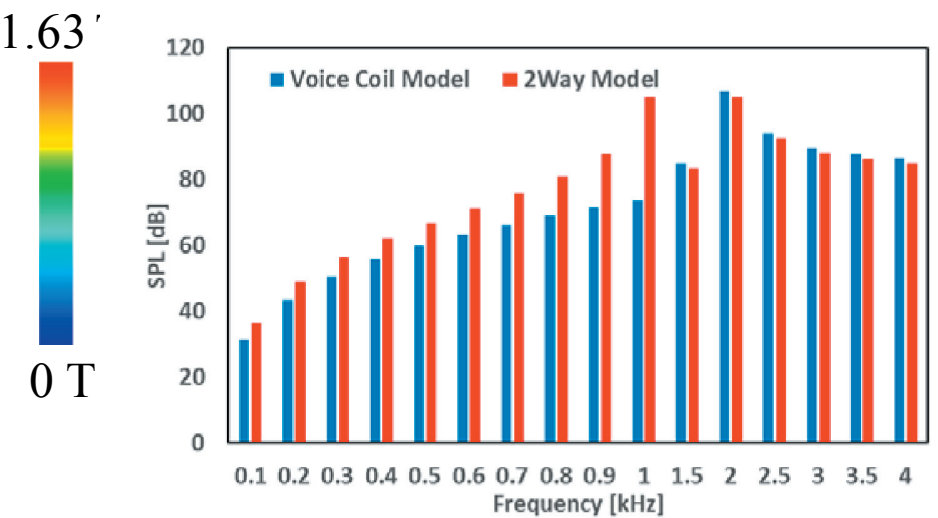

Fig.10 Sound pressure level. 


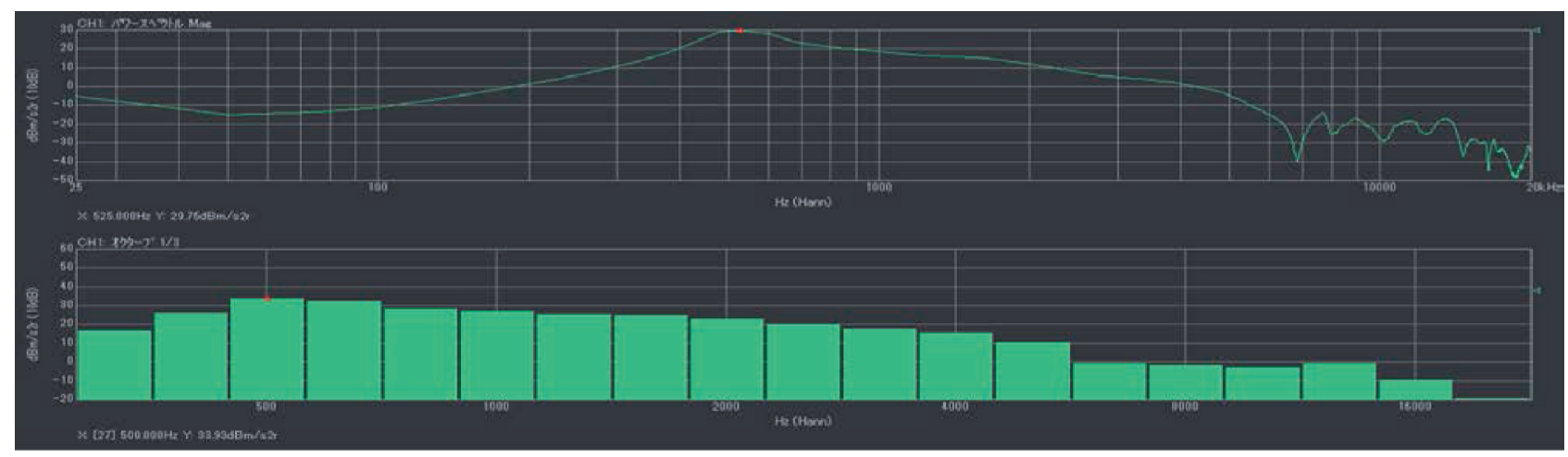

Fig.11 Measurement result of basic voice coil model.

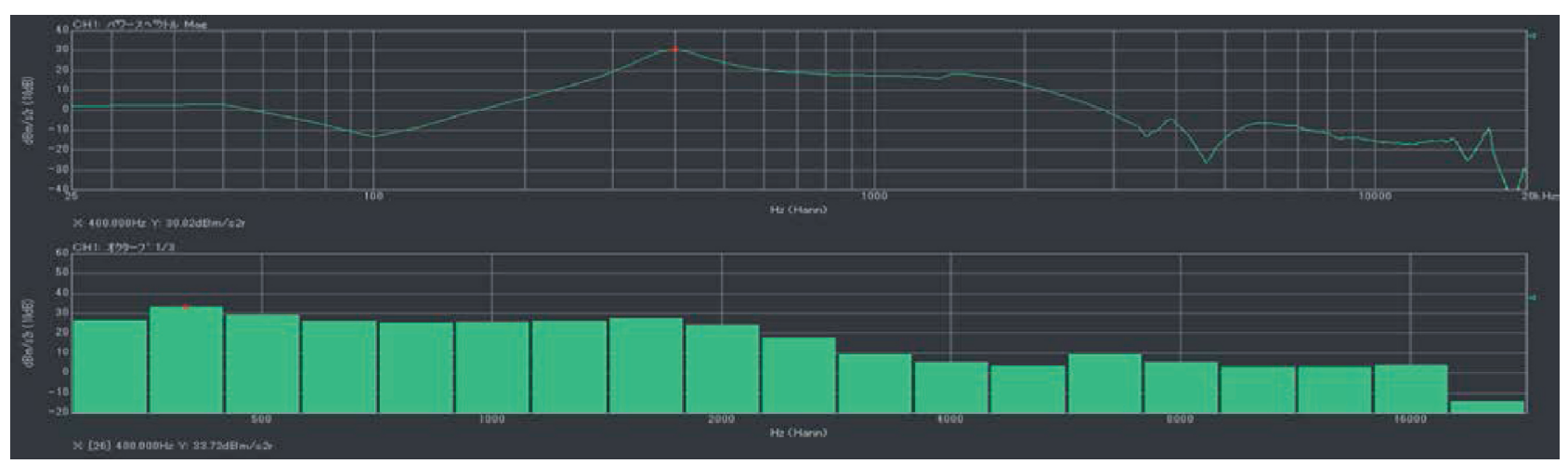

Fig.12 Measurement result of 2 way model.

ルモデルの最大出力は $33.93 \mathrm{dBm} / \mathrm{s}^{2} \mathrm{r}$ であるが， $500 \mathrm{~Hz}$ 以下の周波数域において出力が低く, $4 \mathrm{kHz}$ 以上の周 波数域の出力も低くなる傾向が読み取れる。Fig.12よ り, サンプルの最大出力は $33.72 \mathrm{dBm} / \mathrm{s}^{2} \mathrm{r}$ であり, 250 $2 \mathrm{kHz}$ 間では比較的フラットな特性を示していること が分かる。

\section{5 結言}

本稿では，骨伝導スピーカに関する技術や原理また それらに使用される基本構造例とその解析について述 べた。この骨伝導スピーカの技術は, 今後また盛り上 がりを見せ，一般消費者の目にも多く留まる製品とな る可能性を多く秘めている。この技術のさらなる発展 が期待される。

\section{参考文献}

[1] 吉川 滉也, 北川 亘, 竹下 隆晴, 増田 明弘, 中嶋 政広, 中谷 明子, 中谷 任徳, 小型骨伝導スピーカの設 計と特性解析, 電磁力関連のダイナミクスシンポジウム (SEAD2015),pp91-96
[2] Koya Yoshikawa, Wataru Kitagawa, Takaharu Takeshita, Akihiro Masuda,Masahiro Nakashima, Akiko Nakatani,and Hidenori Nakatani, Design and Characteristic Analysis for New Structure of Bone ConductionSpeaker, 21th International Conference on Electrical Machines(ICEM 2014),Proceedings of ICEM 2014

[3] Koya Yoshikawa, Wataru Kitagawa, Takaharu Takeshita, Akihiro Masuda, Masahiro Nakashima, Akiko Nakatani,and Hidenori Nakatani, Improvement Efficiency and Miniaturization of Bone Conduction Speaker, Asia Pacific Symposium on Applied Electromagnetics and Mechanics(APSAEM2014),Proceedings of APSAEM 2014

[4] 吉川 滉也, 北川 亘, 竹下 隆晴, 増田 明弘, 中嶋 政広，低周波域拡大のための骨伝導スピーカの設計と特 性解析, 第 24 回 MAGDA コンファレンス in Tohoku(MAGDA2015),pp409-414

[5] J. W. Kim and M. J .Bae, A Study on Hearing Loss According to Sound Pressure Level of The Ear-Phone, KEE Trans, Vol. 32, No. 1, pp.1086-1087, 2009.

[6] Xuezhi Zheng, Volski. V, Vandenbosch. G. A. E, and Moshchalkov. V. V, Eigenmode analysis of plasmonic scatterers by volumetric integral equation tech-nique, Antennas and Propagation, pp.618 - 621, 2013.

[7] Meessen. K. J, Paulides. J. J. H, and Lomonova. E. A, Force Calculations in 3-D Cylindrical Structures Using Fourier Analysis and the Maxwell Stress Tensor, IEEE Trans Vol.49, pp. $536-545,2013$. 